\title{
Evaluation of the genomic DNA extracted from formalin-fixed, paraffin-embedded oral samples archived for the past 40-years
}

\author{
Avaliação do DNA genômico obtido de biópsias de boca embebidas em parafina e arquivadas por até 40 anos
}

Tatiana Nayara Libório;; Adriana Etges ${ }^{2}$, Adriana da Costa Neves³ ${ }^{3}$ Ricardo Alves Mesquita4; Fábio Daumas Nunes ${ }^{5}$

\section{key words}

Paraffin-embedded tissues

DNA

PCR

Formalin

\section{abstract}

Background: The most common human archival specimens are formalin-fixed, paraffin-embedded tissues (PETs). DNA can be extracted from PETs, but sometimes, it is unsuitable for molecular techniques as slow degradation of DNA occurs with time. Objective: The aim of this study was to verify and discuss if samples of oral PETs archived for the past 40-years are possible substrates for molecular biology studies, using PCR. Methods: The samples were submitted to phenol-chloroform extraction method. DNA was qualified and quantified by spectrophotometer analysis, electrophoresis and amplification by PCR. Results: It was observed a weak positive correlation between genomic DNA yield and specimen age. The agarose gel electrophoresis demonstrated that genomic DNA length was more frequently composed of small fragments. The 268-bp fragments of the $\beta$-globin gene was amplified in $55 \%$ of cases and preferentially in more recent ones, which showed strong amplification if compared with older samples. WAF1 gene with 149-bp presented weak but detectable amplification in $75 \%$ of cases. The 536 -bp fragment of $\beta$-globin gene was detected in $25 \%$ of samples. The amplification was intense in genomic DNA extracted from recent cases and weak in older ones. Conclusion: This study shown that, despite degradation, it is possible to use genomic DNA obtained from PETs, archived for the past forty years, in PCR amplification of small DNA products, being large DNA fragments more difficult to amplificate. resumo

Introdução: O material fixado em formol e embebido em parafina constitui hoje a maior fonte de tecido humano arquivado. O DNA extraído de tecido parafinado por vezes não é adequado para as técnicas de biologia molecular, visto que se apresenta parcialmente degradado. Objetivos: 0 objetivo desse estudo foi verificar se tecido humano de boca parafinado e arquivado pelos últimos 40 anos pode ser usado para a reação em cadeia da polimerase (PCR). Métodos: Amostras foram submetidas à técnica de extração de DNA pelo método do fenol-clorofórmio. Para quantificação e qualificação do DNA foram realizadas análise em espectrofotômetro, eletroforese em gel de agarose e amplificação pela técnica da PCR. Resultados: Foi observada fraca correlação positiva entre a quantidade de DNA obtida e a idade das amostras. A eletroforese em gel de agarose demonstrou que a maioria do DNA obtido foi constituída de fragmentos pequenos. O fragmento de 268-pb do gene da $\beta$-globina foi amplificado em $55 \%$ dos casos, preferencialmente nos casos mais recentes. 0 fragmento de 149-pb do gene WAF1 apresentou amplificação fraca, mas presente em $75 \%$ dos casos. O fragmento de 536-bp do gene da $\beta$-globina foi detectado em somente $25 \%$ dos casos e também preferencialmente nos casos mais recentes. Conclusões: Esse estudo mostrou que, apesar de o DNA estar degradado, é possível usar DNA genômico extraído de tecido parafinado arquivado pelos últimos 40 anos em reações de PCR de produtos pequenos. $A$ amplificação de produtos maiores, entretanto, é mais difícil. unitermos

Tecido parafinado

DNA

$P C R$

Formol

1. MS; professor of the Oral Pathology Department, Dentistry School, Universidade Federal do Amazonas (UFAM), Brazil.

2. Ph.D.; professor of the Oral Pathology Department. Dentistry School. Universidade Federal de Pelotas (UFPel), Rio Grande do Sul, Brazil.

3. Ph.D.; researcher of the Department of Cenetics, Instituto Butantan, São Paulo, Brazil.

4. Ph.D., professor of the Oral Pathology, Medicine and Surgery Department of the Dentistry School, Universidade Federal de Minas Cerais (UFMC), Brazil.

5- Ph.D.; professor of the Oral Pathology Department of the Dentistry School, Universidade de São Paulo (USP), Brazil.

The research was performed in Oral Pathology Department of the School of Dentistry, USP, Brazil.

Sponsor by Conselho Nacional de Desenvolvimento Cientifico e Tecnológico (CNPq) and Fundação Coordenação de Aperfeiçoamento de Pessoal de Nível Superior (CAPES). 


\section{Introduction}

The polymerase chain reaction (PCR) is an in vitro amplification method that depends, for successful results, on the adequate storage of samples, and a good protocol for DNA extraction ${ }^{(3,10,17)}$. Methods for DNA extraction from fresh tissue and cytological preparation have been described and adapted for use in archival specimens. The most common human archival specimens are formalin-fixed, paraffin-embedded tissues (PETs). DNA can be extracted from PETs, but archival material may be unsuitable for most molecular techniques which require high molecular weight genomic DNA, as slow degradation of DNA occurs with time. However, short DNA segments are also useful as a substrate for $\mathrm{PCR}^{(10)}$. Some authors have shown that PCR can be performed successfully on nucleic acids (NA) that are partially degraded over time ${ }^{(1,3,10,12,14,17)}$. Pavelic et al. showed that formalin caused irreversible DNA damages that were greater with prolonged fixation time, making it suitable only for PCR amplification ${ }^{(15)}$.

In the current study, we evaluated the genomic DNA extracted from oral PETs archived for the past forty years. It was analyzed the DNA purity, yield, length and PCR amplification.

\section{Materials and methods}

The experimental protocol was approved by the Committee of Bioethics in Research from Dentistry School, University of São Paulo, São Paulo, Brazil ( $\mathrm{n}^{\circ}$ 1.272/2003).

\section{Tissue samples}

Formalin fixed, paraffin-embedded tissue samples from 30 oral inflammatory fibrous hyperplasia were selected from the files of the Oral Pathology Service at the University of São Paulo (USP), Brazil. Three cases were randomly selected every five years from 1960 to 2003 (Table 1).

\section{Genomic DNA extraction}

Ten sections of $10 \mu \mathrm{m}$ were collected from each case and transferred to a $1.5 \mathrm{ml}$ microtube. Extraction of genomic DNA was performed by the phenol-chloroform extraction method, according with Isola et al. ${ }^{(9)}$ and Mesquita et al.(13).

\section{Genomic DNA purity, yield and length}

Genomic DNA purity was assessed with a spectrophotometer (DU-640; Beckman, Palo Alto, CA, EUA) and calculated by ratio of the DNA optical density (OD 260) and protein optical density (OD 280). Genomic DNA yield was calculated from DNA optical density (OD 260) for clean DNA samples. Genomic DNA length was analyzed by electrophoresis pattern of sample aliquots $(10 \mu \mathrm{l})$ in a $0.7 \%$ agarose gel (Seakem GTG, FMC Bioproducts, Uppsala, Sweden) stained with ethidium bromide $(0.5 \mathrm{~g} / \mathrm{ml}$; Invitrogen, Carlsbad, CA, USA) and visualized under ultraviolet light.

\section{Polymerase chain reaction}

Genomic DNA was amplified by PCR with primers of $\beta$-globin and WAF1 genes (Table 2). For all reactions, it was used $25 \mu$ l of reaction mixture containing $2 \mathrm{U}$ of Taq polymerase (Invitrogen, Carlsbad, CA, USA), x 10 PCR buffer (Tris-HCL 200mM, pH 8,4; KCl $500 \mathrm{mM}$ ), 0,3 mM of dNTP (deoxyribonucleotide triphosphate, dATP, dTTP, $\mathrm{dCTP}, \mathrm{dGTP}$ ). Primers and the $\mathrm{MgCl}_{2}$ concentrations were optimized according to the different pairs (Table 2). It was used 100-400ng of DNA sample. The PCR conditions were as follows: denaturation at $94^{\circ} \mathrm{C}$ for $2-3$ minutes, followed by $35-38$ cycles of amplification at $94^{\circ} \mathrm{C}$ for 1 minute, annealing at $52-58^{\circ} \mathrm{C}$ (Table 2) for 1 minute and at $72^{\circ} \mathrm{C}$ for 40-50 seconds followed by an additional extension during 7 minutes at $72^{\circ} \mathrm{C}$. The melting temperature and the number of cycles for each pair of primer are presented in Table 2. Purified DNA from an oral fibroma was used as a positive control, and sterile distilled water was used as a negative control. The fragments of DNA amplification were visualized in electrophoresis with $2 \%$ agarose gel stained with ethidium bromide under ultraviolet light.

\section{Statistical analysis}

To determine correlation between genomic DNA yield and specimen age, Pearson's correlation test was applied. For statistical analysis, the software BioEstat 3.0 was used. Statistical significance was evaluated at .05 level.

\section{Results}

The genomic DNA yield and purity varied from 0.182 to $3.605 \mathrm{ng} / \mu \mathrm{l}$ and 1.22 and $1.99 \mathrm{nmol} / \mathrm{ml}$, respectively 
Case, storage time, yield and purity of DNA extracted $(n=30)$, Oral Pathology Service of São Table 1 Paulo University (2005)

\begin{tabular}{|c|c|c|c|}
\hline Case & Storage time (year) & Yield (ng/pl) & Purity (nmol/ml) \\
\hline 1 & 1960 & 1,388 & 1,66 \\
\hline 2 & 1960 & 1,06 & 1,81 \\
\hline 3 & 1960 & 0,402 & 1,8 \\
\hline 4 & 1965 & 0,674 & 1,83 \\
\hline 5 & 1965 & 0,241 & 1,22 \\
\hline 6 & 1965 & 0,381 & 1,86 \\
\hline 7 & 1970 & 0,746 & 1,79 \\
\hline 8 & 1970 & 0,239 & 1,6 \\
\hline 9 & 1970 & 1,17 & 1,77 \\
\hline 10 & 1975 & 0,621 & 1,74 \\
\hline 11 & 1975 & 0,638 & 1,77 \\
\hline 12 & 1975 & 3,64 & 1,76 \\
\hline 13 & 1980 & 0,244 & 1,62 \\
\hline 14 & 1980 & 0,977 & 1,74 \\
\hline 15 & 1980 & 0,587 & 1,66 \\
\hline 16 & 1985 & 0,532 & 1,7 \\
\hline 17 & 1985 & 0,293 & 1,54 \\
\hline 18 & 1985 & 0,182 & 1,49 \\
\hline 19 & 1990 & 1,01 & 1,68 \\
\hline 20 & 1990 & 1,448 & 1,77 \\
\hline 21 & 1990 & 1,235 & 1,74 \\
\hline 22 & 1995 & 0,961 & 1,81 \\
\hline 23 & 1995 & 0,392 & 1,85 \\
\hline 24 & 1995 & 3,082 & 1,84 \\
\hline 25 & 2000 & 2,431 & 1,75 \\
\hline 26 & 2000 & 0,774 & 1,8 \\
\hline 27 & 2000 & 3,605 & 1,89 \\
\hline 28 & 2003 & 2,027 & 1,99 \\
\hline 29 & 2003 & 2,314 & 1,9 \\
\hline 30 & 2003 & 3,302 & 1,88 \\
\hline
\end{tabular}

\section{Table 2 (2005)}

\section{Conditions of the polymerase chain reaction. Oral Pathology Service of São Paulo University}

\begin{tabular}{|c|c|c|c|c|c|}
\hline Primer sequence & $\begin{array}{l}\text { Product Size } \\
\text { (base pairs) }\end{array}$ & $\begin{array}{c}\text { Primer } \\
\text { concentration (pM) }\end{array}$ & $\operatorname{TM}\left({ }^{\circ} \mathrm{C}\right)$ & $\begin{array}{c}\text { Number of } \\
\text { cycles }\end{array}$ & $\begin{array}{c}\mathrm{MgCl}_{2} \text { concentration } \\
(\mathrm{mM})\end{array}$ \\
\hline $\begin{array}{l}\beta \text {-globin } \\
5^{\prime} \text { aggtacggctgtcatcactt } 3^{\prime} \\
5^{\prime} \text { cctcaccaccaacttcatcc } 3^{\prime}\end{array}$ & 268 & 500 & 52 & 38 & 2 \\
\hline $\begin{array}{l}\beta \text {-globin } \\
5^{\prime} \text { gccatctattgcttacatttgc } 3^{\prime} \\
5^{\prime} \text { aaacatcaagggtcccatag } 3^{\prime}\end{array}$ & 536 & 500 & 55 & 39 & 3 \\
\hline $\begin{array}{l}\text { WAF } 1 \\
5^{\prime} \text { ggcctgcccaagctctacct } 3^{\prime} \\
5^{\prime} \text { ggcacaagggtacaagacag } 3^{\prime}\end{array}$ & 149 & 250 & 58 & 35 & 3 \\
\hline
\end{tabular}


(Table 1). It was observed a weak positive correlation between genomic DNA yield and specimen age $(r=0.49)$ $(p=0.006)$. Higher DNA yield was observed on the last decade (1995-2003) (Figure 1).

The electrophoresis showed genomic DNA predominantly of short length. Higher DNA fragments were evident in the last two decades (1985-2003) (Figure 2).

The 268-bp fragment of the $\beta$-globin gene was amplified in 55\% of cases and preferentially in more recent ones (19902003), which showed strong amplification if compared with older samples (1960-1965) (Figure 3A). WAF1 gene (149 bp) presented weak but detectable amplification in $75 \%$ of all cases (Figure 3B). The 536-bp fragment of $\beta$-globin gene was detected in $25 \%$ of samples. The amplification was intense in genomic DNA extracted from recent cases (2003) and weak in older ones (Figure 3C).

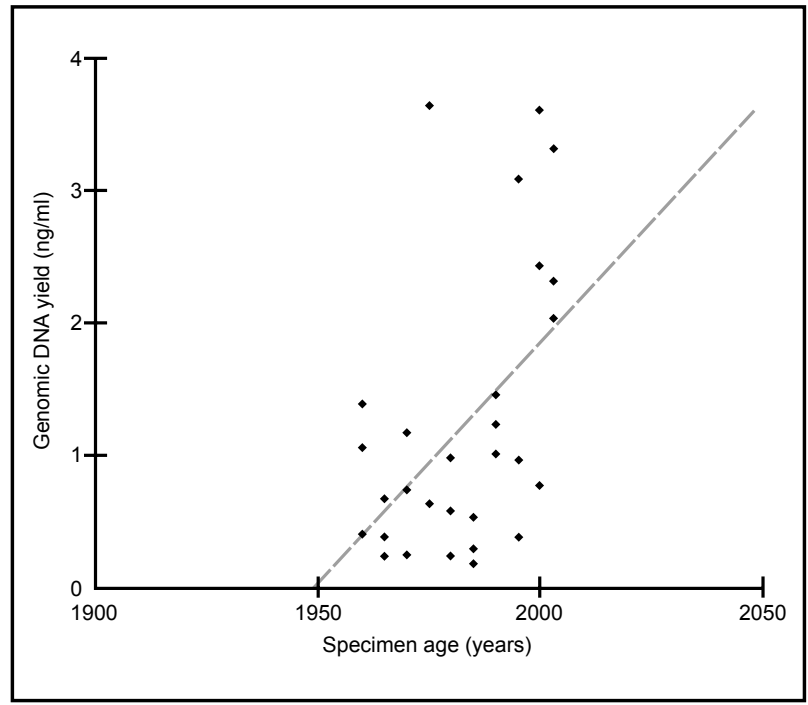

Figure 1 - Correlation between genomic DNA yield and specimen age

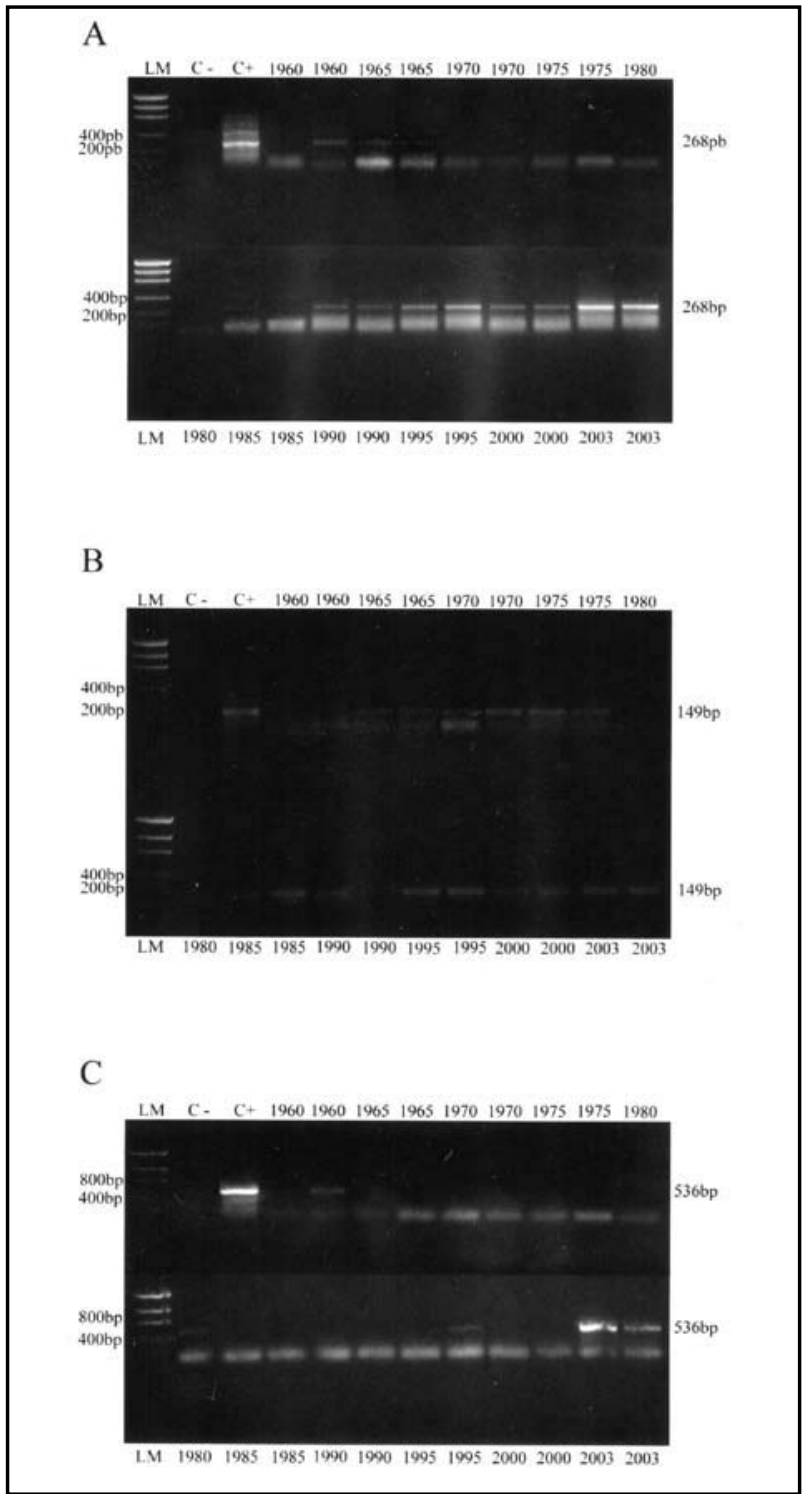

Figure 3 - Amplicon of $\beta$-globin-268 (A), WAF1 (B) and $\beta$-globin-536 (C) genes from genomic DNA obtained from different storage time archival tissue (PCR technique; original magnification)

LM: low mass; C-: negative control; C+: positive control.

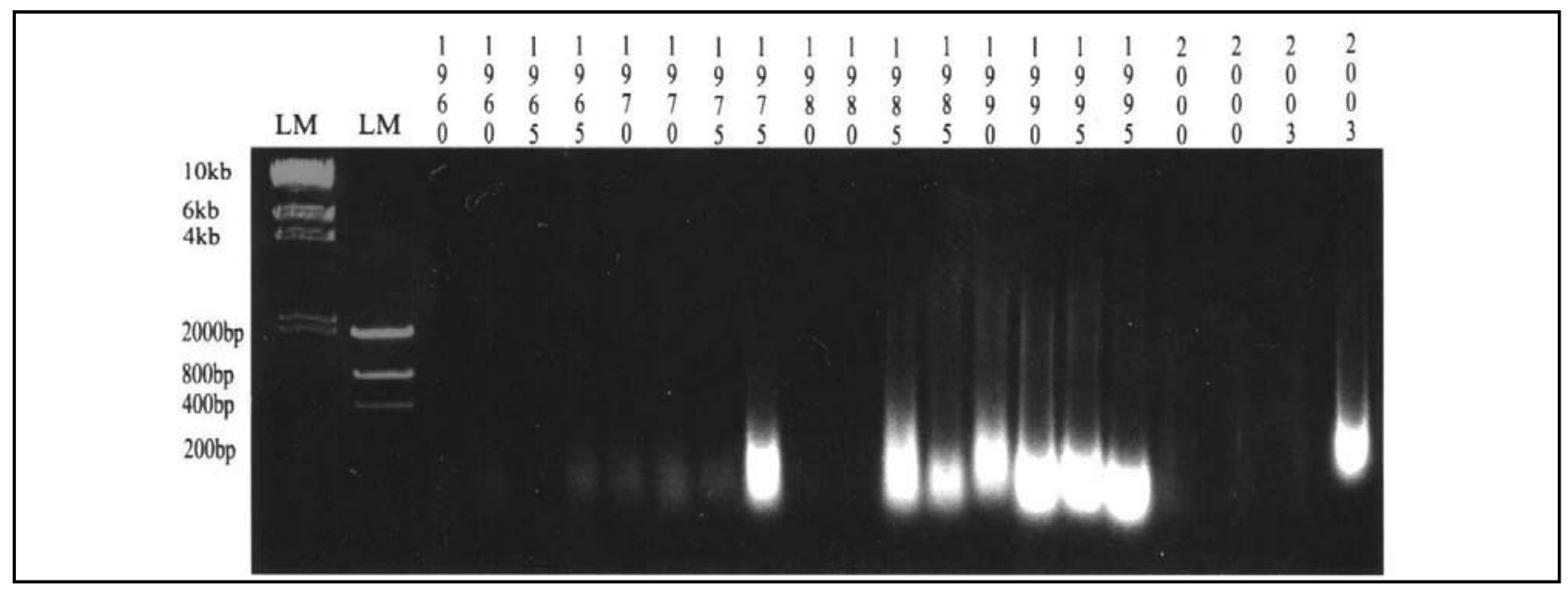

Figure 2 - Electrophoresis gel of genomic DNA extracted from archival tissue from different storage time (xylene-phenol-chroform technique; original magnification) LM: low mass. 


\section{Discussion}

The use of molecular techniques on archival material has been limited due to the difficulty in obtaining consistent results. It is accepted that genomic DNA extracted from PETs is not well preserved or is degraded, and some molecular techniques require high-molecular-weight $\mathrm{DNA}^{(16,17)}$. Our results showed that, despite degradation, it is possible to use genomic DNA, obtained from PETs archived for the past forty years, in PCR amplification of short specific sequences.

Electrophoretic migration of DNA fragments showed that most samples studied presented low-molecularweight DNA. Besides, genomic DNA yield showed high concentration, principally in cases of the last decade (1995-2003). The reasons why PETs undergo degradation include insufficient neutralization of the formalin, causing acid depurination of DNA, preventing amplification ${ }^{(17)}$. The best means of avoiding nucleic acid (NA) loss is by the establishment of covalent bonds between NA and NA and proteins. The most reactive components in NA structure are the amino groups on the bases which are kept non reactive because of the hydrogen bonds. The denaturation process, with heating, destroys those hydrogen bonds exposing the amino groups of the bases, opposing any renaturation of the NA that may occur with cooling $(5,10,11)$. Degradation of DNA by formalin is higher and increases during embedding in paraffin, when high temperatures are used ${ }^{(2,4,12)}$. During storage of paraffin blocks, DNA degradation may continue at a low level ${ }^{(6,8,12)}$. Therefore, it is possible to understand why in this study the higher-molecular-weight and the higher yield of genomic DNA were seen preferentially in more recent cases. In addition, the use of PETs to retrospective studies with molecular analysis requires the use of primers that generate smaller amplification products, because large DNA fragment are more difficult to be amplificated ${ }^{(7)}$. This is in accordance with our results, which showed that as the size of the amplified fragment was increased from 149 to $536 \mathrm{bp}$, a significant decrease of amplification was detected. The most dramatic effect of specimen age was seen when the amplified fragment size was increased to 536bp. Here a linear decrease on the number of successful amplification was observed (Figure 3).

PCR inhibitory factors which are found in genomic DNA extracted from PETs are the high concentration of small DNA fragments that appear to compete with template DNA and denatured protein, which cannot be completely removed by phenolic DNA extraction ${ }^{(12)}$. A large number of $3^{\prime}$-end of small DNA fragments that are not long enough to allow efficient amplification serve as abortive PCR template and compete for the enzyme Taq polymerase ${ }^{(12)}$. Besides this, in the case of low template concentration, the relative primer excess makes more likely Taq-related primer extension and primer dimmer formation resulting from 3' primer complementarity. These primer dimmers will compete with template with the result that low or absent amplification can occur in these situations ${ }^{(5)}$.

In this study, we have chosen the conventional xylenephenol-chroform method, as it is a commonly used DNA extraction method, easy to proceed and supported in various researches of the literature ${ }^{(7,12)}$. This method proves to be useful to extract genomic DNA obtained from PETs, archived for the past forty years, which could be amplified by PCR.

\section{Conclusions}

This study shown that, despite degradation, it is possible to use genomic DNA obtained from PETs, archieved for the past forty years, in PCR amplification of small DNA products, being large DNA fragments more difficult to amplificate.

\section{Acknowledgements}

The authors thank to the Conselho Nacional de Desenvolvimento Científico e Tecnológico (CNPq) and Fundação Coordenação de Aperfeiçoamento de Pessoal de Nível Superior (CAPES). Ricardo Alves Mesquita and Fábio Daumas Nunes are research fellows of the CNPq.

\section{References}

I. AKALU, A.; REICHARDT, J. K. V. A reliable PCR amplification method for microdissected tumor cells obtained from paraffin-embedded tissue. Genet Anal, v. I 5, n. 6, p. 229-33, 1999.
2. BEN-EZRA, J. et al. Effect of fixation on the amplification of nucleic acids from paraffin-embedded material by the polymerase chain reaction. J Histochem Cytochem, v. 39, n. 3, p. 35।-4, | 991 . 
3. COATES, P. J. et al. Simplified procedures for applying the polymerase chain reaction to routinely fixed paraffin wax sections. J Clin Pathol, v. 44, n. 2, p. I 15-8, 1991

4. CRISAN, D.; MATTSON, J.C. Retrospective DNA analysis using fixative tissue specimens. DNA Cell Biol, v. I2, n. 5, p. 45564, 1993.

5. DIAZ-CANO, S. J.; BRADY, S. P. DNA extraction from formalinfixed, paraffin-embedded tissues: protein digestion as a limiting step for retrieval of high-quality DNA. Diagn Mol Pathol, v. 6, n. 6, p. 342-6, 1997.

6. GOELZ, S. E.; HAMILTON, S. R.; VOGELSTEIN, B. Purification of DNA from formaldeyde fixed and paraffin-embedded tissues. Biochem Biophys Res Commun, v. I30, n. I, I I 8-26, 1985.

7. GREER, C. E. et al. PCR amplification from paraffin-embedded tissues. Effects of fixative and fixation time. Am J Clin Pathol, v. 95, n. 2, p. || 7-24, I99|.

8. HOWE, J. R.; KLIMSTRA, D. S.; CORDON-CARDO, C. DNA extraction from paraffin-embedded tissues using a saltingout procedure: a reliable method for PCR amplification of archival material. Histol Histopathol, v. I2, n. 3, p. 595-60I, 1997.

9. ISOLA, J. et al. Analysis of changes in DNA sequences copy number by comparative genomic hybridization in archival paraffin-embedded tumor sample. Am J Pathol, v. I 45, n. 6, p. | $301-8,1994$.

10. JACKSON, D. P. et al. Tissue extraction of DNA and RNA and analysis by the polymerase chain reaction.J Clin Pathol, v. 43, n. 6, p. 499-504, 1990.

I I. KILGALLEN, C. et al. Long-chain PCR on archival material for rapid detection of point mutations and molecular screening for prognostic factors in neoplastic progression. Lab Invest, v. 76, p. $182 \mathrm{~A}, 1997$.

12. KÖSEL, S. et al. Inter-laboratory comparison of DNA preservation in archival paraffin-embedded human brain tissue from participating centres on four continents. Neurogenetics, v. 3, n. 3, p. 163-70, 2001.

13. MESQUITA, R. A. et al. Avaliação de três métodos de extração de DNA de material parafinado para amplificação de DNA genômico pela técnica da PCR. Pesq Odontol Bras, v. 15, n. 4, p. 3|4-9, $200 \mid$.

14. MIES, C. Molecular biological analysis of paraffin-embedded tissues. Hum Pathol, v. 25, n. 6, p. 555-60, 1994.

15. PAVELIC, J. et al. PCR amplification of DNA from archival specimens. A methodological approach. Neoplasma, v. 43, n. 2, p. 75-81, 1996.

16. SATO, Y. et al. Comparison of the DNA extraction methods for polymerase chain reaction amplification from formalinfixed and paraffin-embedded tissues. Diagnostic Molecular Pathology, v. 10, n. 4, p. 265-7I, 2001.

17. SHIBATA, D.; MARTIN, W...; ARNHEIM, N. Analysis of DNA Sequences in forty-year-old paraffin-embedded thin-tissue sections: a bridge between molecular biology and classical histology. Cancer Research, v. 48, n. 16, p. 4564-6, 1988. 